\title{
Application of the TG-MS system in studying sewage sludge pyrolysis and gasification
}

\author{
Tomasz Bedyk, Lech Nowicki, Paweł Stolarek, Stanisław Ledakowicz \\ Technical University of Lodz, Faculty of Process and Environmental Engineering, ul. Wólczańska 213, 90-924 Łódź, \\ e-mail: tbedyk@wipos.p.lodz.pl
}

\begin{abstract}
A method of monitoring sewage sludge pyrolysis and gasification was proposed. Samples of sludge were pyrolysed in Ar and gasified in $\mathrm{CO}_{2}$ in a thermobalance. The evolved gases were analysed on the calibrated MS, the samples of sludge and solid residues at different stages of the processes were subjected to elemental analysis. The identification and the quantitative characterisation of chemical reactions were performed, based on the DTG and MS profiles.
\end{abstract}

Keywords: sewage sludge, pyrolysis, gasification, thermal analysis, mass spectrometry.

\section{INTRODUCTION}

Sewage sludge is an unavoidable by-product of the wastewater treatment process. The utilisation of the growing quantities of formed sludges is becoming one of the most important ecological problems nowadays $\mathbf{1}$. The traditional ways of sewage sludge disposal, such as storage on lagoons, agricultural utilization or incineration, may cause secondary pollutions of soil, ground water and air. One of the alternative methods of sewage sludge utilization is the gasification process, i.e. partial oxidation in the presence of $\mathrm{CO}_{2}, \mathrm{O}_{2}$ or steam. The synthesis gas and inert ash are the products of this process - gas can be utilized for power generation or chemical syntheses ${ }^{2,3,4}$. Gasification of coal is a well-known process and has been used for many years ${ }^{5}$, but the gasification of sewage sludge still needs further investigations $\mathbf{4 , 6}$.

The aim of this work is to demonstrate a monitoring method of sewage sludge pyrolysis and gasification processes. By coupling thermogravimetry (TG) with mass spectrometry (MS) it was possible to follow the mass loss of the sewage sludge sample and record the gaseous products on-line. Based on the TG-MS data the identification of the chemical reactions occurring in the processes and their quantitative characterisation were performed.

\section{EXPERIMENTAL}

The Mettler-Toledo TGA/SDTA851 LF (temperature range $20 \div 1100^{\circ} \mathrm{C}$, sample mass up to $5000 \mathrm{mg}$ ) thermobalance was coupled with the Balzers ThermoStar Mass Spectrometer QMS 200. A special TG-MS conversion kit was used. The gas supplying system consisting of three calibrated mass flow meters (the Brooks model 4850S) was set to control the feed gas flow rate and gas composition. The content of $\mathrm{C}, \mathrm{H}, \mathrm{N}, \mathrm{S}$ and $\mathrm{O}$ in the raw samples of sewage sludge and for the samples on a different stage of the process was determined by the CE Instruments NA 2500. elemental analyser.

The TG-MS system provides extensive information on the solid products or the evolved substances. Both analy- sis methods result in a complete picture of the ongoing reactions during the gasification process.

In order to use the results obtained from the TG-MS system for a quantitative analysis of reaction products, the MS profiles recorded as relative intensity must be converted into the composition of evolved gases. Two calibration methods of the MS signals were proposed:

1. External standard - a two-component mixture of inert gas (Ar) and $\mathrm{CO}$ or $\mathrm{CO}_{2}$ or $\mathrm{H}_{2}$ or $\mathrm{CH}_{4}$ was prepared outside of the TG-MS system by using precise mass flow meters set on specified flow rates for each component.

2. Internal standard - the calibration gas was produced or consumed by chemical reaction occurring in the thermobalance. On the basis of sample mass loss measured in the TG the molar fraction of the produced or consumed gas can be calculated and compared with the MS signal.

For the external standard method the relationship between the gas mole fraction of individual components and the relative intensity of the MS signals (RI) can be described with high accuracy by the straight lines ${ }^{7}$. The slopes of the calibration lines for all the components are presented in Table 1.

For the internal standard method the reaction of $\mathrm{CuO}$ reduction in $\mathrm{CO}$ or $\mathrm{H}_{2}$ atmosphere was performed ${ }^{\mathbf{8}}$ :

$$
\mathrm{CuO}(\mathrm{s})+\mathrm{CO}(\mathrm{g}) \rightarrow \mathrm{Cu}(\mathrm{s})+\mathrm{CO}_{2}(\mathrm{~g})
$$$$
\mathrm{CuO}(\mathrm{s})+\mathrm{H}_{2}(\mathrm{~g}) \rightarrow \mathrm{Cu}(\mathrm{s})+\mathrm{H}_{2} \mathrm{O}(\mathrm{g})
$$

The amount of the evolved $\left(\mathrm{CO}_{2}\right.$ or $\left.\mathrm{H}_{2} \mathrm{O}\right)$ and consumed gases $\left(\mathrm{H}_{2}\right.$ or $\left.\mathrm{CO}\right)$ can be easily calculated from the mass loss determined from the TG measurement and stoichiometric balance.

In Fig. 1 the DTG curves practically overlaps with the MS signals in the whole range of temperatures, which confirms the linear character of the calibration curve. The mole fraction of the calibrated gas in the outlet was calculated from the equation (3).

$$
\mathrm{y}_{\mathrm{x}}=\frac{\frac{\mathrm{DTG} \mathrm{m}_{\mathrm{CuO}} \beta}{\mathrm{M}_{\mathrm{O}}}}{\frac{\mathrm{Q}_{\mathrm{S}} \rho_{\mathrm{S}}}{\mathrm{M}_{\mathrm{S}}}+\frac{\mathrm{Q}_{\mathrm{Ar}} \rho_{\mathrm{Ar}}}{\mathrm{M}_{\mathrm{Ar}}}}
$$

Table 1. The slopes of calibration lines calculated on the basis of the external and internal standard methods

\begin{tabular}{|l|c|c|c|c|c|}
\hline gas & $\mathrm{H}_{2}$ & $\mathrm{CH}_{4}$ & $\mathrm{H}_{2} \mathrm{O}$ & $\mathrm{CO}$ & $\mathrm{CO}_{2}$ \\
\hline $\mathrm{m} / \mathrm{z}$ & 2 & 16 & 18 & 28 & 44 \\
\hline external standard & 1.011 & 1.358 & - & 1.003 & 0.826 \\
\hline internal standard & 0.959 & - & 0.980 & 1.142 & 0.840 \\
\hline
\end{tabular}


(a)

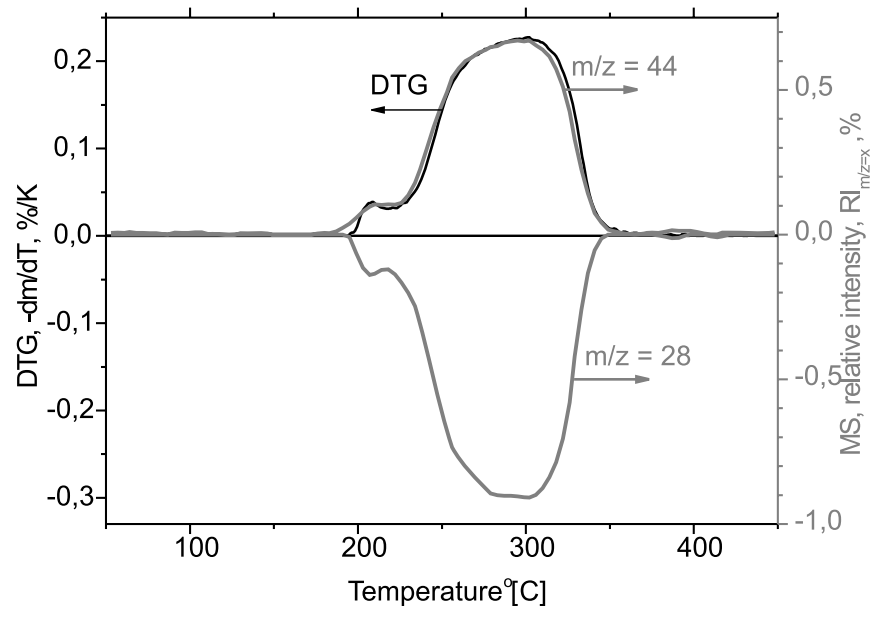

(b)

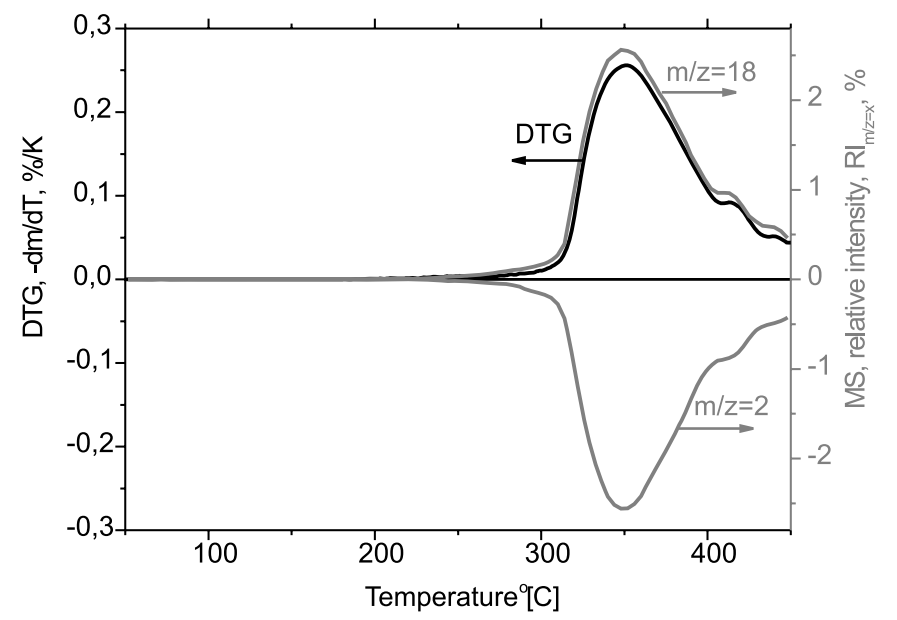

Figure 1. A comparison of the DTG curve and the relative intensity of $\mathrm{m} / \mathrm{z}$ signals for the reaction of $\mathrm{CuO}$ reduction in $\mathrm{CO}$ (a) and $\mathrm{H}_{2}$ (b) atmosphere

where: the DTG - the value of the DTG signal, \%/K, $\mathrm{m}_{\mathrm{CuO}}$ - the initial sample mass $(25,0 \mathrm{mg}), \beta$ - the heating rate $(10 \mathrm{~K} / \mathrm{min}), \mathrm{M}$ - the molecular weight, $\mathrm{Q}$ - the inlet gas the flow rate, $\rho$ - gas density, subscripts: $\mathrm{S}=\mathrm{CO}$ or $\mathrm{H}_{2}$, Ar - argon, $\mathrm{O}$ - atomic oxygen. By making a comparison of the calibrated gas mole fraction with the relative intensity of $\mathrm{m} / \mathrm{z}$ signal a slope of the calibration lines coefficient can be obtained (Table 1).

The values of the slope of the calibration lines calculated on the basis of both methods are close, however for $\mathrm{CO}$ the difference is higher (about 14\%). For further analysis the values from the internal standard method were accepted as more accurate.

Samples of the digested sewage sludge from the municipal wastewater treatment plant (GOŚ Łódź) were used for our investigation. Sewage sludge was dried in air at $110^{\circ} \mathrm{C}$ for 12 hours in an oven to decrease the moisture content to about $5 \%$, then ground and sieved to obtain a uniform size fraction less than $40 \mathrm{~mm}$. The sample was heated in thermobalance with a constant heating rate $(20 \mathrm{~K} / \mathrm{min})$ to the temperature of $1000^{\circ} \mathrm{C}$ in the inert $(\mathrm{Ar}, 40 \mathrm{ml} / \mathrm{min})$ or reactive $\left(50 \% \mathrm{CO}_{2} / 50 \% \mathrm{Ar}, 80 \mathrm{ml} / \mathrm{min}\right)$ atmosphere.

\section{RESULTS AND DISCUSSION}

\section{Quantitative analysis of pyrolysis products}

In Fig. 2 the relative intensity of the chosen MS signals and the DTG curve for the process of sewage sludge pyrolysis are presented.

Because of the absence of reactive atmosphere, the total mass of the evolved gases during the process should be equal to the mass loss observed in thermobalance. To compare the DTG curve with the MS signals, these have to be converted to the same units by the following equation:

$\mathrm{MS}_{\mathrm{x}}=\frac{\mathrm{RI}_{\mathrm{x}} \mathrm{Q}_{\mathrm{Ar}} \mathrm{M}_{\mathrm{x}}}{\mathrm{a}_{\mathrm{x}} \beta \mathrm{m}_{0} \mathrm{M}_{\mathrm{Ar}}}$

where: $\mathrm{RI}_{\mathrm{x}}$ - the relative intensity of the MS signal for component $\mathrm{x}, \mathrm{a}_{\mathrm{x}}$ - the slope of the calibration line, $\mathrm{m}_{\mathrm{o}}-$ the initial mass of the sample.

For the mass balance of the sewage sludge pyrolysis process, the following gases were taken into account: $\mathrm{H}_{2}(\mathrm{~m} / \mathrm{z}=2), \mathrm{H}_{2} \mathrm{O}$ (18), $\mathrm{CO}(28), \mathrm{CO}_{2}$ (44), $\mathrm{CH}_{4}$ (16)

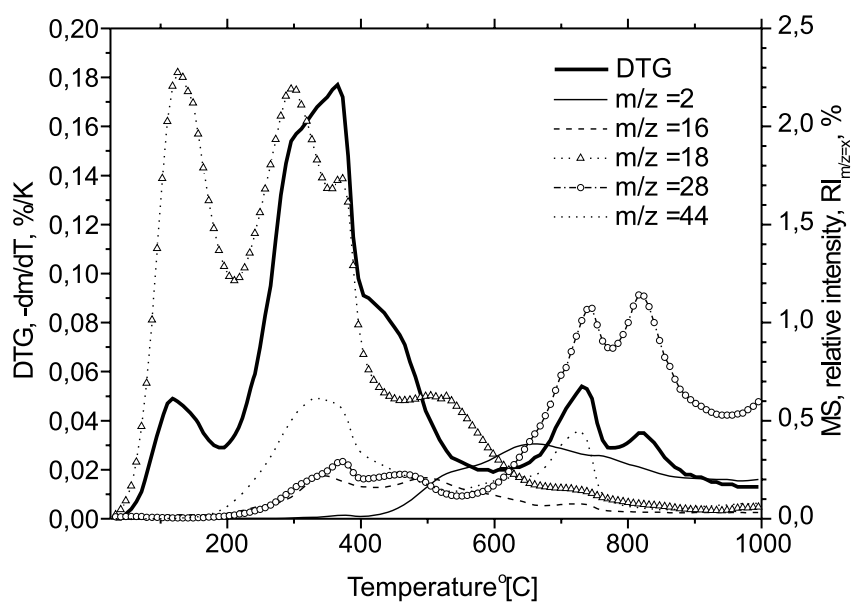

Figure 2. The DTG curve and the relative intensity of the chosen MS signals for pyrolysis of the GOS sample

$\mathrm{C}_{2} \mathrm{H}_{6}$ (27), $\mathrm{C}_{3} \mathrm{H}_{8}$ (41), $\mathrm{C}_{4} \mathrm{H}_{10}$ (55), $\mathrm{CH}_{3} \mathrm{OH}$ (31), $\mathrm{C}_{2} \mathrm{H}_{5} \mathrm{OH}(46) \mathrm{C}_{6} \mathrm{H}_{6}(78), \mathrm{SO}_{2}$ (48) and $\mathrm{H}_{2} \mathrm{~S}$ (34). For all the components except the calibrated gases the $\mathrm{a}_{\mathrm{x}}$ values were assumed to be the same as for $\mathrm{CH}_{4}$.

In Fig. 3 a quantitative comparison of the DTG curve and the rate of the produced gases is presented. The DTG signal and the rate of the total gas production curve overlap, except for the temperatures range $200-500^{\circ} \mathrm{C}$, where

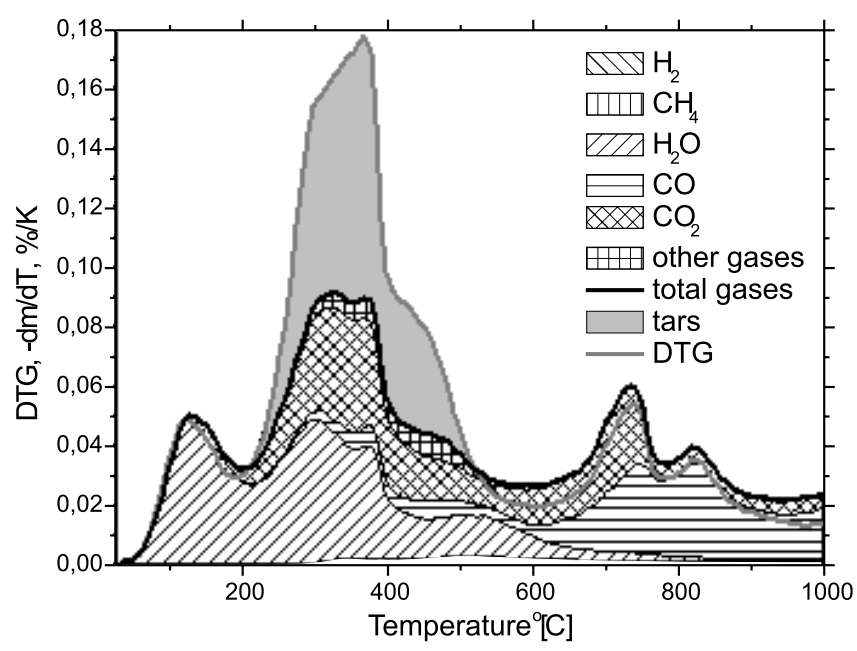

Figure 3. A quantitative comparison of the DTG signal and the rate of the produced gases and tars for pyrolysis 
Table 2. The composition of the products formed during the whole process of pyrolysis and its particular stages

\begin{tabular}{|c|c|c|c|c|c|c|c|c|c|c|c|c|c|c|}
\hline \multirow{2}{*}{ gas } & $\mathrm{H}_{2}$ & $\mathrm{H}_{2} \mathrm{O}$ & $\mathrm{CO}_{2}$ & $\mathrm{CO}$ & $\mathrm{CH}_{4}$ & $\mathrm{C}_{2} \mathrm{H}_{6}$ & $\mathrm{C}_{3} \mathrm{H}_{8}$ & $\mathrm{C}_{4} \mathrm{H}_{10}$ & $\mathrm{CH}_{3} \mathrm{OH}$ & $\mathrm{C}_{2} \mathrm{H}_{5} \mathrm{OH}$ & $\mathrm{C}_{6} \mathrm{H}_{6}$ & $\mathrm{SO}_{2}$ & $\mathrm{H}_{2} \mathrm{~S}$ & tars \\
\hline & \multicolumn{14}{|c|}{ mass fraction, $\%$} \\
\hline $25-180^{\circ} \mathrm{C}$ & - & 98.0 & 0.8 & 0.7 & - & - & 0.2 & - & - & - & - & - & - & - \\
\hline $180-400^{\circ} \mathrm{C}$ & - & 32.1 & 20.2 & 2.6 & 0.8 & 0.9 & 0.9 & 0.3 & 0.3 & 0.1 & 0.1 & 0.2 & 0.2 & 41.2 \\
\hline $400-600^{\circ} \mathrm{C}$ & 0.7 & 24.7 & 24.3 & 8.8 & 3.9 & 3.3 & 3.3 & 1.2 & 0.1 & - & 0.3 & 0.1 & 0.1 & 29.2 \\
\hline $600-1000^{\circ} \mathrm{C}$ & 2.1 & 6.6 & 28.7 & 59.6 & 1.5 & 0.8 & 0.4 & 0.1 & - & - & 0.2 & 0.1 & - & - \\
\hline $25-1000^{\circ} \mathrm{C}$ & 0.7 & 29.8 & 21.9 & 17.8 & 1.5 & 1.3 & 1.2 & 0.4 & 0.2 & 0.1 & 0.1 & 0.2 & 0.1 & 24.8 \\
\hline
\end{tabular}

the rate of gas production is distinctly smaller than the mass loss of the sample. This difference can be explained by the forming tars at these temperatures, 10,11 that are condensing before the MS detector. The rate of the produced tars can be evaluated by subtracting the rate of the gas production curve from the DTG signal.

On the basis of the area under the curves in Fig. 3 the composition of all the products formed during the whole process of pyrolysis and its particular stages $\left(25-180^{\circ} \mathrm{C}\right.$, $180-400^{\circ} \mathrm{C}, 400-600^{\circ} \mathrm{C}, 600-1000^{\circ} \mathrm{C}$ ) was calculated (Table 2).

\section{A quantitative analysis of the gasification products}

The presence of $\mathrm{CO}_{2}$ in reactive atmosphere makes it difficult to analyse quantitatively the sewage sludge gasification products by the MS, because $\mathrm{m} / \mathrm{z}=44$ signal and other MS signals included in the mass spectrum of $\mathrm{CO}_{2}$ are distorted. It is also difficult to determine precisely the base line for $\mathrm{CO}_{2}$.

In Fig. 4 the selected MS signals for pyrolysis and gasification processes are presented. Most of the signals are similar for both processes, which confirms that all reactions occurring during the sewage sludge pyrolysis occur also in reactive atmosphere to the same extent ${ }^{4}$. Moreover, in the $\mathrm{CO}_{2}$ atmosphere several chemical reactions occur, which can be quantitatively analysed on the basis of the difference of the DTG curves for gasification and pyrolysis (G-P DTG) (Fig. 5). At temperatures below $550^{\circ} \mathrm{C}$ the G-P DTG curve is close to zero. However, in the temperature range of $550-755^{\circ} \mathrm{C}$ a positive peak with the maximum at $725^{\circ} \mathrm{C}$ appears. It is surprising that the observed rate of mass loss is higher for pyrolysis than for gasification. This phenomenon can be explained by the

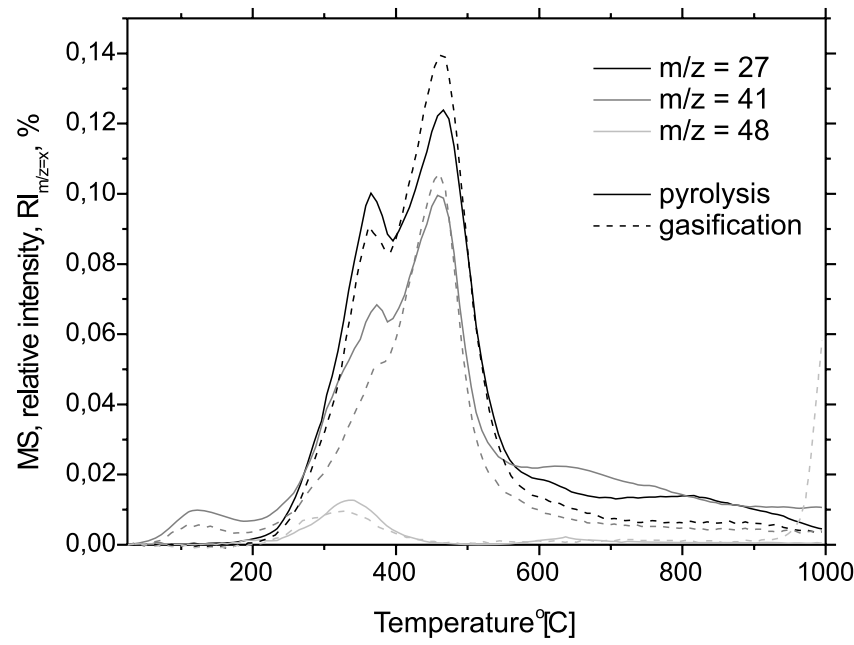

Figure 4. The selected MS signals for pyrolysis and gasification processes

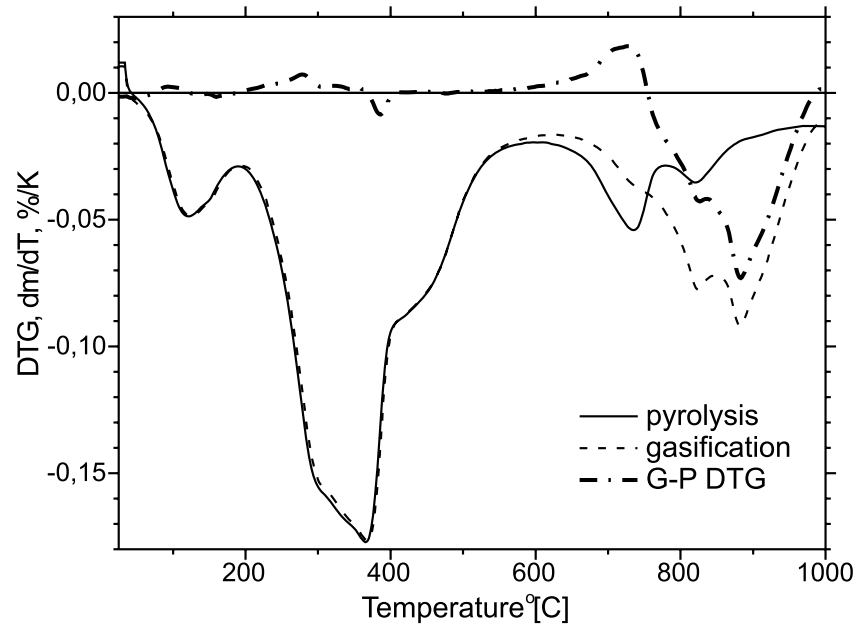

Figure 5. The DTG curves for pyrolysis and gasification and their difference (G-P DTG)

oxidation reaction of substances $\mathrm{X}$ contained in the solid sample, forming non-volatile oxides:

$\mathrm{X}(\mathrm{s})+\mathrm{CO}_{2}(\mathrm{~g}) \rightarrow \mathrm{XO}(\mathrm{s})+\mathrm{CO}(\mathrm{g})$

In the higher temperature range $755-1000^{\circ} \mathrm{C}$ (with the maximum at $880^{\circ} \mathrm{C}$ ) gasification of pyrolytic char occurs according to reaction ${ }^{\mathbf{1 2}, \mathbf{1 3}}$ :

$\mathrm{C}(\mathrm{s})+\mathrm{CO}_{2}(\mathrm{~g}) \rightarrow 2 \mathrm{CO}(\mathrm{g})$

These reactions $(5-6)$ can be described quantitatively by a calculation of sample mass increase/decrease from the area under the G-P DTG curve.

At temperatures above $950^{\circ} \mathrm{C}$ an increase of the $\mathrm{RI}_{\mathrm{m} / \mathrm{z}=48}$ and $\mathrm{RI}_{\mathrm{m} / \mathrm{z}=64}$ signals is observed (see Fig. 4), which corresponds to $\mathrm{SO}_{2}$ emission according to reaction: $\mathrm{S}(\mathrm{s})+2 \mathrm{CO}_{2}(\mathrm{~g}) \rightarrow \mathrm{SO}_{2}(\mathrm{~g})+2 \mathrm{CO}(\mathrm{g})$

On the basis of the experiments carried out it is no possible to determine quantitatively the rate of reaction (7), because it does not complete until the temperature of $1000^{\circ} \mathrm{C}$. The quantity of the produced and consumed gases in this reaction was calculated, based on the difference in sulphur content in the solid samples after pyrolysis and gasification determined by the elemental analysis (see Table 5).

It is worth noticing that at temperatures above $550^{\circ} \mathrm{C}$ the rate of $\mathrm{H}_{2}$ production in reactive atmosphere is lower than in inert gas (Fig. 6). This is the result of the watergas shift reaction ${ }^{\mathbf{1 3}}$ :

$\mathrm{H}_{2}(\mathrm{~g})+\mathrm{CO}_{2}(\mathrm{~g}) \leftrightarrow \mathrm{H}_{2} \mathrm{O}(\mathrm{g})+\mathrm{CO}(\mathrm{g})$

This reaction is not connected with the mass loss of the solid sample, because all the reagents and products are in the gas phase. However, the water-gas shift reaction changes the composition of the gas phase essentially. The rate of reaction (8) was calculated as a difference of the 
Table 3. The mass balance of sewage sludge gasification

\begin{tabular}{|l|c|c|c|c|c|c|c|c|c|c|}
\hline & solid & $\mathrm{H}_{2}$ & $\mathrm{H}_{2} \mathrm{O}$ & $\mathrm{CO}_{2}$ & $\mathrm{CO}$ & $\mathrm{C}_{\mathrm{x}} \mathrm{H}_{\mathrm{y}}$ & \multicolumn{2}{c|}{$\mathrm{SO}_{2}$} & $\mathrm{H}_{2} \mathrm{~S}$ & tars \\
\cline { 2 - 10 } & \multicolumn{8}{|c|}{$\%$ of the initial sample mass } & - & - \\
\hline inlet & 100 & - & - & $37.8^{1}$ & - & - & 1.51 & 0.05 & 13.5 \\
\hline outlet & $42.3^{2}$ & 0.15 & 18.1 & 6.59 & 57.5 & 1.89 & 1.51 & - \\
\hline
\end{tabular}

${ }_{1}^{1}$ The amount of $\mathrm{CO}_{2}$ consumed in reactions $(5-8)$

2 The remaining inert ash

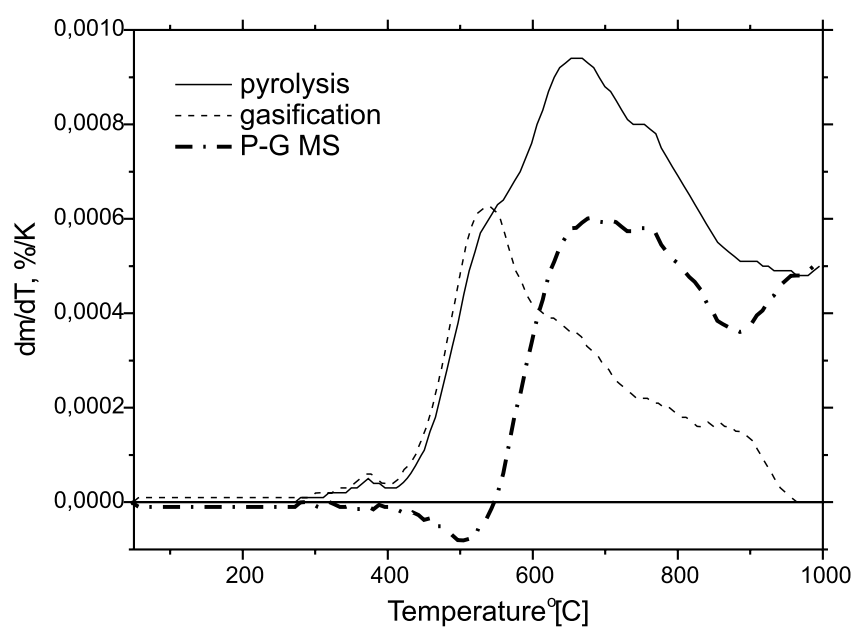

Figure 6. The rate of $\mathrm{H}_{2}$ production in pyrolysis and gasification and their difference (P-G MS)

$\mathrm{MS}_{\mathrm{m} / \mathrm{z}=2}$ signals recorded for pyrolysis and gasification (the P-G MS curve in Fig. 6).

In Table 3 the mass balance of sewage sludge gasification is presented. The assumption that all $\mathrm{CO}_{2}$ produced at temperatures above $550^{\circ} \mathrm{C}$ is consumed in gasification, oxidation and the water-gas shift reactions, was made.

In Table 4 the calculated mass and the molar fractions of sewage sludge gasification are presented. It should be noted that the main gaseous product of sewage sludge gasification by $\mathrm{CO}_{2}$ is carbon monoxide. The content of $\mathrm{CO}$ in the gas phase amounts about 60 mol- $\%$ and $66 \mathrm{wt}-\%$.

The balance of the elements for sewage sludge pyrolysis and gasification processes

The content of $\mathrm{C}, \mathrm{H}, \mathrm{N}, \mathrm{S}$ and $\mathrm{O}$ in the sewage sludge and in the samples taken at different stages of the pyrolysis and after gasification was determined by the elemental analysis (Table 5). The content of the basic elements was also calculated, based on the amounts of the produced gases during the pyrolysis process. In Fig. 7 the balance

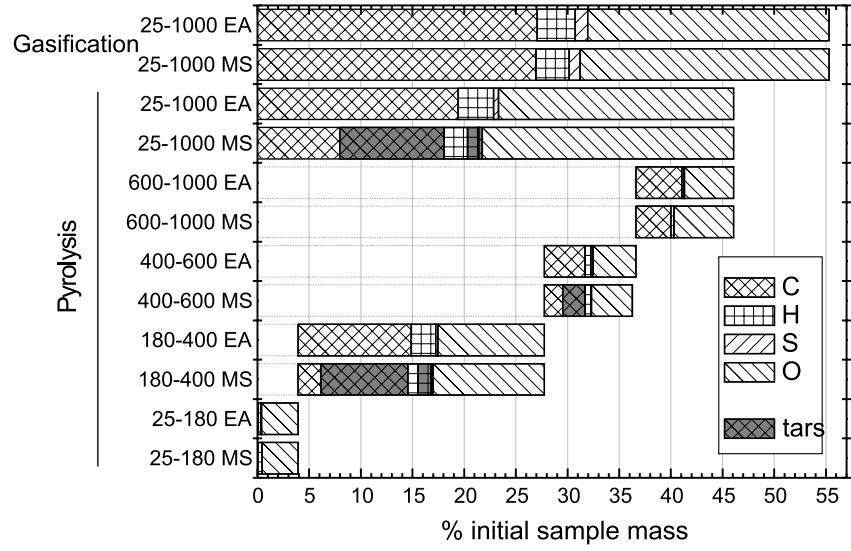

Figure 7. The balance of the elements determined by the elemental analysis (EA) and the TG-MS analysis

of the elements determined by the elemental analysis and the TG-MS analysis, is compared.

In the temperature range of $25-180^{\circ} \mathrm{C}$ and $600-$ $1000^{\circ} \mathrm{C}$ a good agreement of both methods is observed. In other temperatures ranges the observed significant discrepancy is due to the tars produced. On the basis of this discrepancy an approximate elemental content of tar can be estimated as: $\mathrm{C}: \mathrm{H}: \mathrm{S}=1: 1.22: 0.01$. In accordance with the presented balance, the whole elemental oxygen contained in sludge was liberated into the gas phase, mainly as $\mathrm{H}_{2} \mathrm{O}, \mathrm{CO}_{2}$ and $\mathrm{CO}$, and does not build in the structure of tars. Nitrogen was not considered in the elemental balance.

\section{SUMMARY}

- The TG-MS system was proved as a good tool for the monitoring of pyrolysis and gasification processes of sewage sludge.

- The presented method of analysis and mass balance calculations allows an estimation of tars content in the product.

Table 4. The composition of gases evolved during sewage sludge gasification

\begin{tabular}{|c|c|c|c|c|c|c|c|c|c|c|c|c|c|}
\hline \multirow{2}{*}{ product } & $\mathrm{H}_{2}$ & $\mathrm{H}_{2} \mathrm{O}$ & $\mathrm{CO}_{2}$ & $\mathrm{CO}$ & $\mathrm{CH}_{4}$ & $\mathrm{C}_{2} \mathrm{H}_{6}$ & $\mathrm{C}_{3} \mathrm{H}_{8}$ & $\mathrm{C}_{4} \mathrm{H}_{10}$ & $\mathrm{CH}_{3} \mathrm{OH}$ & $\mathrm{C}_{2} \mathrm{H}_{5} \mathrm{OH}$ & $\mathrm{C}_{6} \mathrm{H}_{6}$ & $\mathrm{SO}_{2}$ & $\mathrm{H}_{2} \mathrm{~S}$ \\
\hline & \multicolumn{13}{|c|}{$\%$} \\
\hline mass fraction & 0.18 & 21.0 & 7.62 & 66.4 & 0.94 & 0.81 & 0.77 & 0.25 & 0.11 & 0.04 & 0.08 & 1.74 & 0.06 \\
\hline mole fraction & 2.23 & 29.6 & 4.39 & 60.2 & 1.49 & 0.68 & 0.44 & 0.11 & 0.09 & 0.02 & 0.03 & 0.69 & 0.04 \\
\hline
\end{tabular}

Table 5. The GOS sample elemental analysis

\begin{tabular}{|c|c|c|c|c|c|c|c|c|}
\hline \multirow{2}{*}{\multicolumn{2}{|c|}{ sample }} & $\mathrm{N}$ & $\mathrm{C}$ & $\mathrm{H}$ & $\mathrm{S}$ & $\mathrm{O}^{n}$ & Ash & Total \\
\hline & & \multicolumn{7}{|c|}{$\%$ of the initial sample mass } \\
\hline \multicolumn{2}{|l|}{ raw sample } & 2.78 & 25.97 & 3.50 & 1.14 & 22.74 & 43.88 & 100.0 \\
\hline \multirow{3}{*}{ 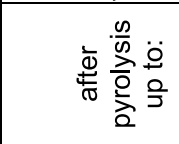 } & $180^{\circ} \mathrm{C}$ & 2.81 & 25.88 & 3.24 & 1.10 & 19.20 & 43.88 & 96.1 \\
\hline & $600^{\circ} \mathrm{C}$ & 0.99 & 10.96 & 0.33 & 0.71 & 4.73 & 43.88 & 61.6 \\
\hline & $1000^{\circ} \mathrm{C}$ & 0.16 & 6.54 & 0.07 & 0.68 & 0.00 & 43.88 & 51.3 \\
\hline \multicolumn{2}{|c|}{ after the gasification } & 0.00 & 0.26 & 0.00 & 0.00 & 0.56 & 43.88 & 44.7 \\
\hline
\end{tabular}


- At temperatures below $550^{\circ} \mathrm{C}$ the processes in inert and reactive atmospheres proceed identically.

- In reactive atmosphere of $\mathrm{CO}_{2}$ gasification occurs with the maximum rate at about $880^{\circ} \mathrm{C}$. Simultaneously the reactions of oxidation, water-gas shift and $\mathrm{SO}_{2}$ formation occur.

- $\mathrm{CO}$ is the main gaseous product of the gasification process in $\mathrm{CO}_{2}$ atmosphere, whereas the amount of the produced hydrogen is relatively low.

- After the process of sewage sludge gasification only the inert ash, containing small amounts of oxygen, remains in the solid phase.

\section{ACKNOWLEDGEMENT}

This work was done within the frames of the 3 T09C 02627 project financed by The Ministry of Science and Higher Education.

\section{LITERATURE CITED}

1. Werther, J. \& Ogada, T. (1999). Sewage sludge combustion. Prog. Energy Combust. Sci. 25 (1), 55 - 116.

2. Inguanzo, M., Domínguez, A., Menéndez, J.A., Blanco, C.G. \& Pis, J.J. (2002). On the pyrolysis of sewage sludge: the influence of pyrolysis conditions on solid, liquid and gas fractions. J. Anal. Appl. Pyrolysis, 63 (1), 209 - 222.

3. Ptasinski, K., Prins, M. \& Pierik, A. (2007). Exergetic evaluation of biomass gasification. Energy, 32 (4), 568 - 574.

4. Stolarek, P. \& Ledakowicz, S. (2001). Thermal processing of sewage sludge by drying, pyrolysis, gasification and combustion. Water Sci. Technol. 44, 333 - 339.

5. Vlaswinkel, E.E. (1992). Energetic analysis and optimisation of an integrated coal gasification-combined cycle power plant. Fuel Process. Technol. 32, 47 - 67.

6. Ferrasse, J.H., Seyssiecq, I. \& Roche, N. (2003). Thermal gasification: a feasible solution for sewage sludge valorisation? Chem. Eng. Technol. 26, 941 - 945.

7. Hoffmann, E., Charette, J. \& Stroobant, V. (1994). Spectrométrie de masse, (c) Masson, Editieur.

8. Ledakowicz, S., Nowicki, L. \& Stolarek, P. (2003). Analiza i modelowanie procesów gaz - ciało stałe $\mathrm{z}$ zastosowaniem mikroreaktorów. In Burghardt A. (Eds.), Reaktory wielofazowe $i$ wielofunkcyjne dla podstawowych procesów chemicznych, biotechnologicznych i ochrony środowiska (pp. 273 - 302). Instytut Inżynierii Chemicznej PAN. Wrocław.

9. Adegoroye, A., Paterson, N., Li, X., Morgan, T., Herod, A.A., Dugwell, D.R. \& Kandi Yoti, R. (2004). The characterisation of tars produced during the gasification of sewage sludge in a spouted bed reactor. Fuel. 83 (14 - 15), 1949 1960.

10. Dogru, M., Midilli, A. \& Howarth, C.R. (2002). Gasification of sewage sludge using a throated downdraft gasifier and uncertainty analysis. Fuel Process. Technol. 75 (1), 55 82.

11. Morris, M. \& Waldheim, L. (1998). Energy recovery from solid waste fuels using advanced gasification technology, Waste Manage. 18 (6 - 8), 557 - 564.

12. Murakami, T., Xu, G., Suda, T., Matsuzawa, Y., Tani, H. \& Fujimori, T. (2007). Some process fundamentals of biomass gasification in dual fluidized bed. Fuel. $86(1-2)$, $244-255$.

13. Midilli, A., Dogru, M., Akay, G. \& Howarth, C.R. (2002). Hydrogen production from sewage sludge via a fixed bed gasifier product gas. Int. J. Hydrogen Energy. 27 (10), $1035-1041$. 